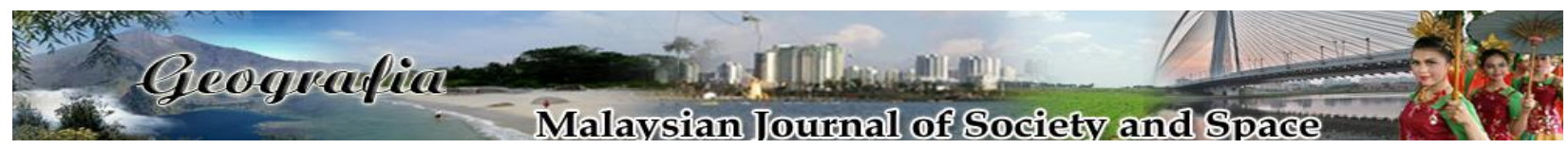

\title{
Differential determinants of gender participation in recreational activities among academic staff of University of Ilorin, Nigeria
}

\author{
Tunde, Afolabi Monisola \\ Department of Geography \& Environmental Management, \\ University of Ilorin, Nigeria
}

Correspondence: Tunde, Afolabi Manisola (email: afolabi@unilorin.edu.ng)

Received: 26 December 2018; Accepted: 4 September 2019; Published: 25 November 2019

\begin{abstract}
Recreational activities can be seen as any activities performed willingly to improve both physical and mental well-being of an individual. This study examines the differential determinants of gender participation in recreational activities among members of academic staff of university of Ilorin, Nigeria. Seventy-four male and seventy female academic members of staff were sampled randomly across all the faculties in the institution. A total number of 148 copies of questionnaire were administered on the sampled respondents. Percentages, tables, factor analysis and Analysis of Variance (ANOVA) were used to analyze the gathered data. Findings revealed that there are 1,117males and 361 females as at January, 2018. Factor 1 (Age) explains the highest percentage of the total variance, followed by Factor 2 (Gender), 3 (academic qualification) and Factor 4 (Employment). Whereas Factor 5 (Accessibility to recreational facilities) explains the lowest percentages of the total variance. The study concluded that awareness should be created for academic members of staff to participate in recreational activities using different recreational facilities available within and outside the institution. This will enhance the physical and psychological wellbeing, thus improving their efficiency.
\end{abstract}

Keywords: academic, factors, gender, recreation, university

\section{Introduction}

Literature has indicated that recreation consists of an activity or experience usually chosen voluntarily by the participants-either because of satisfaction, pleasure or creative enrichment derived. Recreation is very important because the process helps to refresh and reinvigorate human body and mind. It ranges from physical activities such as sports to playing in the garden. It can also be known as a way of visiting the gym for exercise to enhance a healthful living. The Harvard School of Public Health, pointed out that physical activity helps protect people against heart disease, obesity and cancer. It helps in improving mood and sleep quality. The WHO 
(2018) recommends that children and adolescents between 5-17 years should engage in 60 minutes of moderate to vigorous intensity physical activity daily, adults between 18-64, at least 150 minutes per week while aged 65 years and above should do 150 or 75 minutes per week. According to The U.S. Centers for Disease Control and Prevention, two and a half hours of moderate-intensity aerobic exercise, such as walking, water aerobics and gardening, each week is recommended for an individual. This translates to 30 minutes of physical activity five days per week. In spite of all these noted benefits and recommendations, very few people are involved in recreational activities. The problem may be attributed to the fact that people generally do not have adequate knowledge of the health, economic and social benefits of recreation or probably do not really create time for it.

Several studies have been carried out on recreation in Nigeria. For instance, Obinna et al. (2009) studied the patterns and determinants of recreational behaviour in Port-Harcourt, Rivers State, Nigeria and concluded that income was the most significant in explaining recreational behaviour. Emeribe and Akah (2012), examined knowledge, attitude and participation of male and female nurses in recreational activities in Cross River State, Nigeria and discovered that most nurses participate in exercise when they perceive their health is been threatened even though they are aware that recreation improves their health and fitness. Olubor and Osunde (2007), investigated personal study time and leisure among university undergraduates in Southern Nigeria and recommended that among other things, the authorities of Nigerian universities and non-government organizations should provide facilities for indoor games in the halls of residence. Furthermore, Omolawon and Mohammed (2006) conducted a study on perceived determinants associated with non-participation of University of Ibadan academic staff in sports and physical activity; the result showed that occupational demand and availability of sports facilities and equipment were determinant factors in physical activity's involvement. Akindutire and Oyeniyi (2012) examined the factors inhibiting female participation in sport. The findings revealed that parents are not significant inhibiting factor to female participation in sports, but availability of standard facilities and equipment, academic stress and university policy on sports.

In Kwara State, very few studies of this nature have been carried out. What actually aroused the interest in a study of this nature has to do with the fact that the members of academic staff of university of Ilorin, Nigeria especially the female have not really shown interest in recreational activities in spite of the availability of some recreational facilities within the institution. This is in support of documented evidences that some people will still not participate in recreation despite the availability of recreational facilities at their door step (Amusa, 1985; Omolawon \& Mohammed, 2006). Hence, it is against this backdrop that this research work examines the differential determinants of gender participation in recreational activities among members of academic staff of university of Ilorin. Specifically, the study will identify the number of male as against female academic members of staff and their socio-demographic characteristics; examine the relationship between recreation behaviour and socio-demographic characteristics of the respondents; assess academic staff members' opinions on the need to recreate; and determine factors influencing their participation in recreational activities. 


\section{Hypotheses}

The following hypotheses were tested in the study:

1. There is no significant difference(s) in the knowledge of recreational activities by gender

2. There is no significant difference(s) in gender participation in recreational activities

\section{Recreation}

The word recreation has been a subject of discourse in terms of its proper conceptualization and universal acceptability by different scholars; Falade (1990), opined that recreation means consumption of activity than the price paid to participate in it. Olowoyo (1986) noted that recreation is concerned with those activities in which a person voluntarily takes part during hours other than work. However, recreation is something interesting to do in leisure which is done simply for enjoyment of it. Recreational activities is when people or individuals are willing to participate provided they have access to facilities, apart from games, viewing only in parks and reserved. Bucher (1979) defined recreation as socially accepted and worthwhile activities in which a person voluntarily participates during leisure hours and through which he or she has the opportunities to develop physically, mentally, emotionally and socially. Insufficient physical activity according to WHO, (2018) is a fundamental risk factor for non-communicable diseases (NCDs) such as cardiovascular diseases, cancer, diabetes and even death. It can further be described as all activities performed willingly to improve physical as well as mental well-being of an individual. Any socially acceptable worthwhile activities in which a person voluntarily participates during leisure hours and through which he or she has opportunities to develop physically, mentally, emotionally and socially is known as recreation (Bucher ,1983). Recreation can further be seen as the leisure time activities that people choose to carry out in their spare time (Jones, Kennaugh, Parry, \& Ross, 1996). California State Parks, in 2005 listed the health benefits of recreation to include reduction of the risk of chronic disease; reduction of obesity; increase in life expectancy and boosting of the immune system. This study however perceives recreation as indoor and outdoor voluntary activities that can help physical, mental, and social lives of the practitioners for a healthy style of living.

\section{Gender}

According to the United Nations (2007), gender is a culturally specific set of characteristics that identify the social behavior of women and men and the relationship between them. It refers to social differences as opposed to biological ones between women and men that have been learned are changeable overtime and vary widely both within and between cultures. It was further stressed that the term gender does not replace the term sex, which refers exclusively to biological differences between men and women, for example, statistical data are broken down by sex. The distinction created by societies between human beings on the basis of masculinity and feminity in relation to their expected roles in the society is what is regarded as gender (Akinmade, 2000). The term gender as defined by Buckland and Haleegoah (1996), is a concept used in social sciences to look at roles and activities of men and women. These roles are often socially defined as shaped by the tradition and beliefs of a particular culture. Gender does not mean men and women per se but the relations between them both perceptual and material (Gunther \& Zimprich, 1997). They asserted that gender (as distinguished from sex) denotes a socio-structural feature; 
gender roles are biologically determined to a limited extent only they are for the most part socially constructed. Their respective roles are assigned to men or women in a given society and at a given time on the basis of various factors (social, cultural, ideological, religious, ethnic, economic etc). Gender socialization as cited by Nithiya et al. (2018) can be regarded as a form of socialization where children are trained of their gender roles based on the sex assigned to them at birth. Female and Male role allocations therefore differ from one society to another and within societies. Bem (2010), in his own opinion says gender is how a person's biology is culturally valued and interpreted into locally accepted ideas of what is to be a man or woman.

Gender is changeable since it is defined socially and culturally. There are only two sexes but there are many concepts of gender, gender reflects the social idea of femininity and masculinity and has undergone various changes throughout history. Ostergaard (1992) sees gender as qualitative and independent character of women and men's position in the society. Moser (1989), pointed out that in many societies, gender is an important determinant of the distribution of rights, resources and responsibilities among individual household and communities. From the foregoing, gender can be seen as disparities in the socio-cultural roles between men and women.

\section{Study area}

The study area for this research work is University of Ilorin located in Ilorin the capital of Kwara State. University of Ilorin is a Federal University established by a decree of the Federal military Government in August 1975. Ilorin is about $500 \mathrm{~km}$ from Abuja. The university started with 3 faculties and 200 foundation students in October 1975, and has grown steadily into its present 10 faculty structure with a College of Health Sciences, a Postgraduate School and a total student population of over 25,000 and a workforce of about 3,000. Ilorin, the Kwara State capital comprised of three Local Government Areas namely: Ilorin West, Ilorin East and Ilorin South. The city has been selected because of the increased heterogeneous population over the years and urbanization, which made it a good ground for the study of this nature. The city performs the function of a state capital and headquarters for the three local government areas. Ilorin is located on latitude $8^{\circ} 30^{\prime} \mathrm{N}$ and longitude $4^{0} 35^{\prime} \mathrm{E}$ (Figure 1) with an area of about $100 \mathrm{~km}^{2}$ (Kwara State of Nigeria Diary, 2009). The city in its geological settings consists of Pre-Cambian basement complex with an elevation of between $273 \mathrm{~m}$ to $333 \mathrm{~m}$ above sea level. There is an isolated hill (Sobi hills) of about $394 \mathrm{~m}$ above sea level towards the North of the Western part and $200 \mathrm{~m}$ to $346 \mathrm{~m}$ in the East. The city is covered mainly by ferruginous soil on crystalline acidic rock. The pattern of the drainage system of Ilorin is dendritic due to its characteristics. The most important river is Asa River which flows in south-northern direction. Asa River occupies a fairly wide valley and goes a long way to divide Ilorin into two parts namely, the eastern and the western part. The eastern part covers those areas where the GRA is located while the core indigenes areas of Ilorin fall under the western part. The other rivers that drain into Asa River are river Agba, river Alalubosa, river Okun, river Osere and river Aluko. The vegetation is characterized by scattered tall trees such as Baobab, Locust beans, Shear butter, Acacia etc.

According to Adeniyi (2013), the climate of the city is tropical continental with high temperature throughout the year. It is characterized by wet and dry seasons. Ilorin falls within derived savannah vegetal cover with the existence of dry lowland rain forest vegetal cover. The wet season is between March and October while the dry season is between the months of November and February. The mean annual rainfall is $1200 \mathrm{~mm}$. 


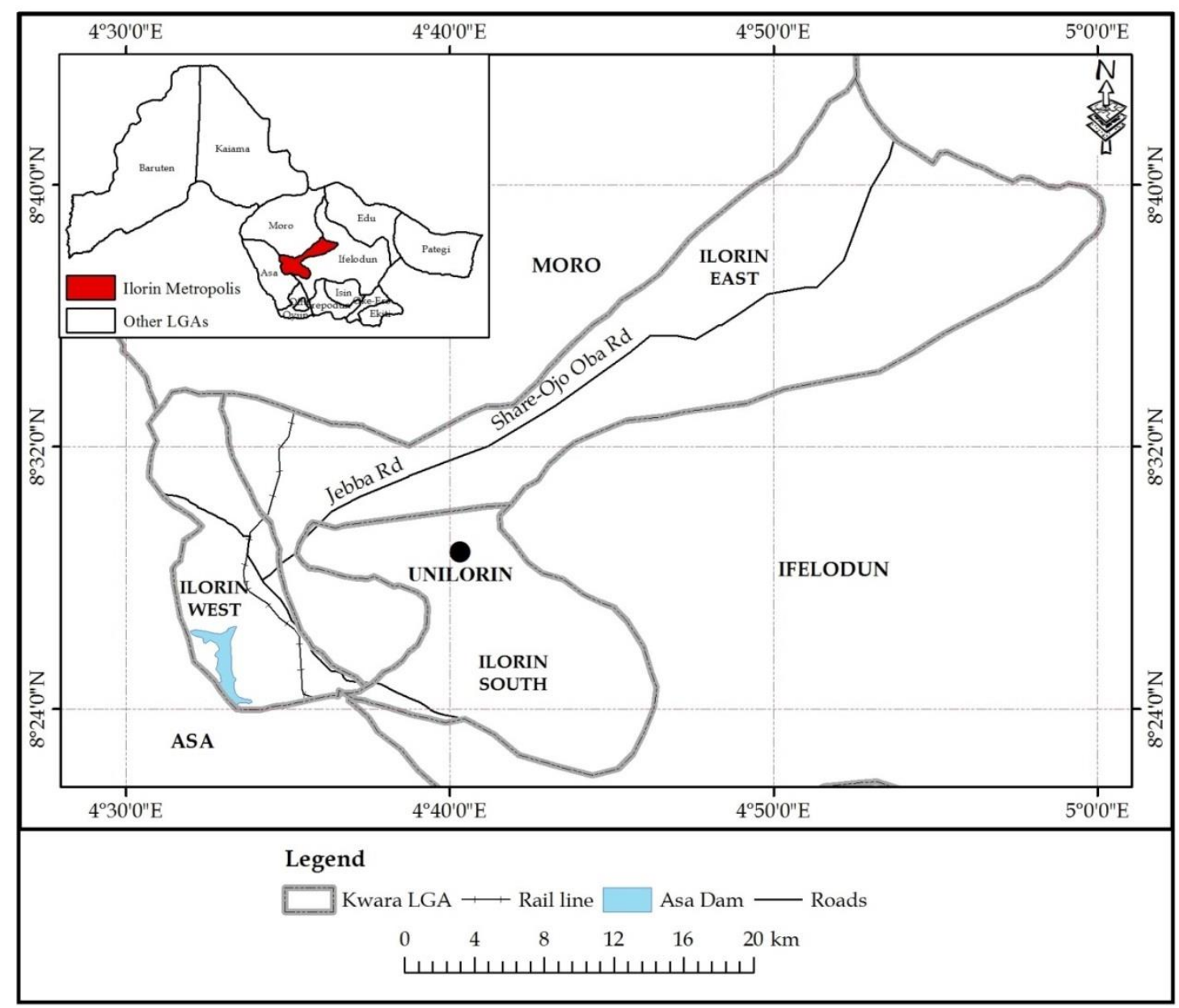

Source: Ministry of Lands and Housing, 2018

Figure 1. Ilorin showing location of University of Ilorin

The 2006 population figures showed that the city has a population of 766,000 (NPC, 2006). Within the metropolis, the major occupation includes distributive trading, civil service of varying cadres and persuasions and a host of informal sector services. Like many traditional cities in Nigeria, Ilorin retains the characteristics of traditional town alongside a modern urban centre. The traditional part of Ilorin is located west of Asa River with a concentric pattern. The centre includes the Emir's palace, Central mosque and Emir's market.

\section{Materials and methods}

For this research work, some of the members of staff of the university both male and female were sampled. A total number of 148 copies of questionnaire representing $10 \%$ of 1,478 total were administered on the sampled respondents. This is in line with Hammond and McCullagh (1978) suggestion that $10 \%$ represents "the agreed minimum sample size". These copies of questionnaire were shared and administered equally on both male and female academic staff of the university. This means seventy-four (74) copies on each gender. To select respondents therefore, there was random selection of male and female academic staff across all the faculties 
in the institution. Percentages, frequency tables, factor analysis and Analysis of Variance (ANOVA) were used to analyze the gathered data.

\section{Results and discussion}

\section{Socio-demographic characteristics of sampled academic staff of University of Ilorin}

The official record of the University of Ilorin revealed that there are 1,478 academic members of staff comprising 1,117 males and 361 females as at January, 2018. Ten percent of this figure was sampled and Table 1 revealed that more than one-quarter of the male respondents are between 40 and 49 years, while only $23.0 \%$ are above 60 years. Majority $(60.8 \%)$ of the female respondents are in their forties, while $13.5 \%$ of them are in their fifties. It can be observed that most of the respondents are in their economic active age and so should be able to participate well in recreational activities. Majority of male $(82.4 \%)$ and female $(86.5 \%)$ respondents respectively are married. The educational status of the respondents shows that majority of the male $(55.4 \%)$ as against the female (47.3\%) respondents have Ph.D. Only 5.4\% male has first degree, similarly, only $19.6 \%$ female respondents have first degree. This is in contrast to Nirmal et al. (2018) report that enrolment in higher education institutions has been mostly dominated by the females.

Table 1. Socio-demographic characteristics of sampled academic staff

\begin{tabular}{|c|c|c|c|c|c|c|c|c|c|}
\hline \multirow{3}{*}{$\begin{array}{l}\text { Socio-economic } \\
\text { Characteristics }\end{array}$} & \multicolumn{6}{|c|}{ Gender } & \multirow{2}{*}{\multicolumn{3}{|c|}{$\begin{array}{c}\text { Total } \\
\text { (M\&F) }\end{array}$}} \\
\hline & \multicolumn{3}{|c|}{ Male } & \multicolumn{3}{|c|}{ Female } & & & \\
\hline & Freq & $\%$ & Cum \% & Freq & $\%$ & Cum \% & Freq & $\%$ & Cum \% \\
\hline \multicolumn{10}{|c|}{ a. Age of Respondents } \\
\hline 18-29 years & 12 & 16.2 & 16.2 & 19 & 25.7 & 25.2 & 31 & 20.9 & 20.9 \\
\hline $30-39$ years & 12 & 16.2 & 32.4 & 0 & 0.0 & 25.2 & 12 & 8.1 & 29.0 \\
\hline $40-49$ years & 31 & 41.9 & 74.3 & 45 & 60.8 & 86.0 & 76 & 51.4 & 80.4 \\
\hline $50-59$ years & 02 & 2.7 & 77.0 & 10 & 13.5 & 99.5 & 12 & 8.1 & 88.5 \\
\hline 60 and above & 17 & 23.0 & 100.0 & 0 & 0.0 & 100.0 & 17 & 11.5 & 100.0 \\
\hline Total & 74 & 100.0 & & 74 & 100.0 & & 148 & 100.0 & \\
\hline \multicolumn{10}{|l|}{ b. Marital Status } \\
\hline Married & 61 & 82.4 & 82.4 & 64 & 86.5 & 86.5 & 125 & 84.5 & 84.5 \\
\hline Single & 12 & 16.2 & 98.6 & 0 & 0.0 & 86.5 & 12 & 8.1 & 92.6 \\
\hline Divorced & 0 & 0.0 & 98.6 & 0 & 0.0 & 86.5 & 0 & 0.0 & 92.6 \\
\hline Separated & 1 & 1.4 & 100.0 & 10 & 13.5 & 100.0 & 11 & 7.4 & 100.0 \\
\hline Total & 74 & 100.0 & & 74 & 100.0 & & 148 & 100.0 & \\
\hline \multicolumn{10}{|c|}{ c. Level of Education } \\
\hline First Degree & 29 & 39.2 & 39.2 & 0 & 0.0 & 0.0 & 29 & 19.6 & 19.6 \\
\hline Masters & 04 & 5.4 & $44 ; 6$ & 39 & 52.7 & 52.7 & 43 & 29.0 & 48.6 \\
\hline Ph. D & 41 & 55.4 & 100.0 & 35 & 47.3 & 100.0 & 76 & 51.4 & 100.0 \\
\hline Total & 74 & 100.0 & & 74 & 100.0 & & 148 & 100.0 & \\
\hline \multicolumn{10}{|c|}{ d. Employment Status } \\
\hline GA & 29 & 39.2 & 39.2 & 0 & 0.0 & 0.0 & 29 & 19.6 & 19.6 \\
\hline $\mathrm{AL}$ & 1 & 1.4 & 40.6 & 32 & 43.2 & 43.2 & 33 & 22.3 & 41.9 \\
\hline Lecturer II & 2 & 2.7 & 43.3 & 10 & 13.5 & 56.7 & 12 & 8.3 & 50.2 \\
\hline Lecturer 1 & 15 & 20.2 & 63.5 & 22 & 29.7 & 86.4 & 37 & 25.0 & 75.2 \\
\hline SL & 20 & 27.0 & 90.5 & 5 & 6.8 & 93.2 & 25 & 16.8 & 92.0 \\
\hline Reader & 4 & 5.4 & 95.9 & 3 & 4.1 & 97.3 & 7 & 4.6 & 96.6 \\
\hline Professor & 3 & 4.1 & 100.0 & 2 & 2.7 & 100.0 & 5 & 3.4 & 100.0 \\
\hline Total & 74 & 100.0 & & 74 & 100.0 & & 148 & 100.0 & \\
\hline
\end{tabular}




\begin{tabular}{llllllllll}
\hline $\begin{array}{l}\text { e. Secondary } \\
\text { Occupation }\end{array}$ & & & & & & & & & \\
None & 38 & 51.3 & 51.3 & 29 & 39.2 & 39.2 & 67 & 45.2 & 45.2 \\
Farming & 17 & 23.0 & 74.3 & 0 & 0 & 39.2 & 17 & 11.5 & 56.7 \\
Fishing & 2 & 2.7 & 77.0 & 12 & 16.2 & 55.4 & 14 & 9.5 & 66.2 \\
Part-time Lecturing & 2 & 2.7 & 79.7 & 10 & 13.5 & 68.9 & 12 & 8.1 & 74.3 \\
Artisan & 1 & 1.4 & 81.1 & 13 & 17.6 & 86.5 & 14 & 9.5 & 83.8 \\
Business & 13 & 17.5 & 98.6 & 0 & 0 & 86.5 & 13 & 8.8 & 92.6 \\
Others & 1 & 1.4 & 100.0 & 10 & 13.5 & 100.0 & 11 & 7.4 & 100.0 \\
$\quad$ Total & 74 & 100.0 & & 74 & 100.0 & & 148 & 100.0 & \\
f. Monthly Income & & & & & & & & & \\
Below 100,000 & 12 & 16.2 & 16.2 & 0 & 0 & 0.0 & 12 & 8.1 & 8.1 \\
100,000-200,000 & 33 & 44.6 & 60.8 & 47 & 63.5 & 63.5 & 80 & 54.0 & 62.1 \\
201,000-300,000 & 19 & 25.6 & 86.4 & 12 & 16.2 & 79.7 & 31 & 20.9 & 83.0 \\
301,000-400,000 & 4 & 5.4 & 91.8 & 10 & 13.5 & 93.2 & 14 & 9.5 & 92.5 \\
$401,000-500,000$ & 3 & 4.1 & 95.9 & 3 & 4.1 & 97.3 & 6 & 4.1 & 96.6 \\
Above 500,000 & 3 & 4.1 & 100.0 & 2 & 2.7 & 100.0 & 5 & 3.4 & 100.0 \\
Total & 74 & 100 & & 74 & 100.0 & & 148 & 100.0 & \\
\hline
\end{tabular}

Source: Researcher's fieldwork, 2018

With regards to the employment status of the respondents, Table 1 further reveals that more than $63.5 \%$ of the male and $86.4 \%$ female respondents respectively are in lecturer 1 and below cadre. It can further be observed from the table that more female lecturers than male are lecturer 1 and below. These are the early career people that have more work to do since they are still at the lower cadre. The monthly income distribution of the respondents' shows that majority $(60.8 \%)$ of the male and female $(63.5 \%)$ respondents earn N200, 000 and below. In addition to this, more than half of the male $(51.4 \%)$ respondents have no secondary occupation, while farming is the most $(23.0 \%)$ common secondary occupation among the male respondents. Similarly, majority of the female $(39.2 \%)$ respondents have no secondary occupation.

\section{Recreational activities}

The recreational activities examined in this study include clubbing, visiting the gym, walking, running, swimming, watching television, gardening, reading, playing ball, jogging, cycling, playing golf, weight lifting, table tennis, singing, dancing, lawn tennis, using treadmill at home and viewing in parks/zoo.

Activities peculiar to the male gender include clubbing, visiting gym, running, swimming, watching television, playing ball, jogging, cycling, playing golf, weight lifting, table tennis and lawn tennis while visiting gym, walking, gardening, reading, singing, dancing, using treadmill at home and viewing are peculiar to the female gender studied. Findings from Table 2 revealed that higher percentage of the sampled male and female respondents are involved more in passive activities. For instance, more male respondents visit club house (94.6\%) and watch television $(100 \%)$, while more female respondents watch television $(81.1 \%)$ dance $(67.6 \%)$, read $(64.9 \%)$, into gardening $(60.8 \%)$, and walk $(60.8 \%)$. 
Table 2. Recreational activities

\begin{tabular}{lll}
\hline Type & Male $=\mathbf{7 4}(\mathbf{\%})$ & Female $=\mathbf{7 4}(\mathbf{\%})$ \\
\hline Clubbing & $70(94.6)$ & - \\
Visiting Gym & $28(37.8)$ & $5(6.8)$ \\
Walking & $25(33.8)$ & $45(60.8)$ \\
Running & $20(27.0)$ & $15(20.3)$ \\
Swimming & $10(7.4)$ & - \\
Watching TV & $74(100)$ & $60(81.1)$ \\
Gardening & $5(6.8)$ & $45(60.8)$ \\
Reading & $5(6.8)$ & $48(64.9)$ \\
Playing Ball & $35(47.3)$ & - \\
Jogging & $30(40.5)$ & - \\
Cycling & $5(6.8)$ & - \\
Playing Golf & $5(6.8)$ & - \\
Weight Lifting & $2(2.7)$ & - \\
Table Tennis & $15(20.3)$ & - \\
Singing & - & $20(27.0)$ \\
Dancing & - & $50(67.6)$ \\
Lawn Tennis & $12(16.2)$ & - \\
Treadmill at home & - & $2(2.7)$ \\
Viewing at parks & $2(2.7)$ & $20(27.0)$ \\
\hline Source: Researcher's fieldwork/computer output, 2018 \\
Note: Percentages are in parentheses and not 100 because of multiple choices
\end{tabular}

\section{Perception of recreation and behaviour of respondents}

\section{Respondents' understanding of recreation}

Table 3 shows respondents' understanding of recreation. As revealed by the Table more than half $(41.9 \%)$ of the male respondents perceived recreation as relaxation, while only $1.4 \%$ perceived recreation as other activities outside work schedule. Similarly, $42.6 \%$ of the female respondents see recreation as relaxation, while only $7.4 \%$ sees recreation as other activities outside work schedule. It can be observed from the table that the respondents have different understanding of recreation.

Table 3. Respondents understanding of recreation

\begin{tabular}{|c|c|c|c|c|c|c|}
\hline \multirow{3}{*}{$\begin{array}{l}\text { Understanding of } \\
\text { Recreation }\end{array}$} & \multicolumn{4}{|c|}{ Gender } & \multirow{2}{*}{\multicolumn{2}{|c|}{ Total }} \\
\hline & \multicolumn{2}{|c|}{ Male } & \multicolumn{2}{|c|}{ Female } & & \\
\hline & Freq & $\%$ & Freq & $\%$ & Freq & $\%$ \\
\hline Leisure Activities & 16 & 21.6 & 22 & 29.7 & 38 & 25.7 \\
\hline Exercise, Games etc & 12 & 16.2 & 0 & 0.0 & 12 & 8.1 \\
\hline Enjoyment and & 2 & 2.7 & 10 & 13.5 & 12 & 8.1 \\
\hline Entertainment & & & & & & \\
\hline Relaxation & 31 & 41.9 & 32 & 43.2 & 63 & 42.6 \\
\hline $\begin{array}{l}\text { Other activities outside } \\
\text { work schedule }\end{array}$ & 1 & 1.4 & 10 & 13.5 & 11 & 7.4 \\
\hline Feeling Good & 12 & 16.2 & 0 & 0.0 & 12 & 8.1 \\
\hline Total & 74 & 100.0 & 74 & 100.0 & 148 & 100.0 \\
\hline
\end{tabular}

Source: Researcher's fieldwork, 2018 
Table 4 revealed the recreational behavior of respondents. It was discovered from the Table that both gender recreate one way or the other in different activities, while the majority (100\%) of male academic staff spent 1-6 hours recreating, the female academic staff spent less than 3 hours. Only 5 male academic staff used public recreational centres, others used paid while none of the female counterparts used public but majority recreate at home.

Table 4. Recreational behaviour of respondents

\begin{tabular}{lll}
\hline Variables & Male $=\mathbf{7 4}(\mathbf{\%})$ & Female $=\mathbf{7 4}(\mathbf{\%})$ \\
\hline Time/hours & & $40(54.1)$ \\
Less 1hr & - & $34(45.9)$ \\
$1-3 \mathrm{hs}$ & $38(51.4)$ & - \\
3-6hrs & $35(47.3)$ & - \\
Above 6hrs & $1(1.4)$ & - \\
Nature & & $5(6.8)$ \\
Public & $5(6.7)$ & $69(93.2)$ \\
Paid/Private & $67(90.5)$ & \\
Home & $2(2.7)$ & - \\
Period & & $44(59.5)$ \\
morning, & $10(13.5)$ & \\
afternoon & - & $23(31.1)$ \\
Evening & $64(86.5)$ & $31(41.9)$ \\
Duration & & $18(24.3)$ \\
Daily & $56(75.7)$ & $2(2.7)$ \\
1-3days/week & $18(24.3)$ & - \\
3-6days/week & - & $7(9.4)$ \\
Weekly & - & $2(2.7)$ \\
Others & - & $15(20.3)$ \\
Company & & $50(67.6)$ \\
Alone & $12(16.2)$ & \\
With friends & $55(74.3)$ & \\
With family & $5(6.8)$ & \\
With Children & $2(2.7)$ & \\
\hline Source: Researcher's fieldwork/computer output, 2018 \\
Note: Percentages are in parentheses
\end{tabular}

Sixty-four $(86.5 \%)$ sampled male academic staff recreate in the evening while only 44 (59.5\%) female academic staff recreate in the evening. Furthermore, $75.7 \%$ male as against $31.1 \%$ female recreate daily. About $74.3 \%$ male and $2.7 \%$ female recreate with friends. This shows male and female have different recreational activities at different time and, different places which are mostly passive in nature.

Relationship between recreational behaviour and socio-demographic characteristics of the respondents

The relationship between recreational behavior of academic staff and socio-demographic characteristics was examined and Table 5 shows a significant but negative relationship between recreation and education $\mathrm{r}(148)=-.208, \mathrm{p}<.05$; employment $\mathrm{r}(148)=-.281, \mathrm{p}<.05$ and income $\mathrm{r}(148)=-.299, \mathrm{p}<.05 ;=.331)$. This means as household size, education, employment status and income of the respondents increase, respondents' interest in recreation decreases. On the other 
hand, Table 5 further shows no significant relationship between recreation behaviour and age, gender, marital status and secondary occupation.

Table 5. Correlation analysis of the relationship between recreation and socio-demographic characteristics of the respondents

\begin{tabular}{llll}
\hline Socio-demographic characteristics & r value & P-value & N \\
\hline Age & $-.177^{*}$ & .032 & 148 \\
Gender & -.054 & .512 & 148 \\
Marital Status & -.089 & .281 & 148 \\
Household size & -.137 & .097 & 148 \\
Education & $-.208^{*}$ & .011 & 148 \\
Employment Status & $-.281^{* *}$ & .001 & 148 \\
Monthly Income & $-.299^{* *}$ & .000 & 148 \\
Secondary Occupation & -.102 & .215 & 148 \\
\hline Source: Researcher's fieldwork/computer output, 2018 & &
\end{tabular}

\section{Independent sample test on gender differences on the need to recreate}

Test on gender differences on the need to recreate was examined. As seen in table 6, the mean value for the male respondents is 2.1216, while that of the female is 2.6757, with standard deviation of .93564 and 1.52700 respectively. The Levene's test shows the differences observed in the mean and standard deviation values are not equal $\mathrm{t}(146)=31.530, \mathrm{p}<.05$. Therefore, for the t-test equality of means of variance, the value obtained under equal variance not assumed will be used as seen in Table 6. The t-test of -2.661 with 146 degree of freedom is significant at .009 level: $\mathrm{t}(146)=-2.661, \mathrm{p}<.05$. Thus, it can be concluded that male and female respondents are significantly different with respects to the need to recreate. By examining the group means and means difference (Group1-male and Group 2-female) it can be revealed that male respondents differ from the female by 0.5541 .

Table 6. Descriptive and independent sample test analysis on gender differences on the need for recreation

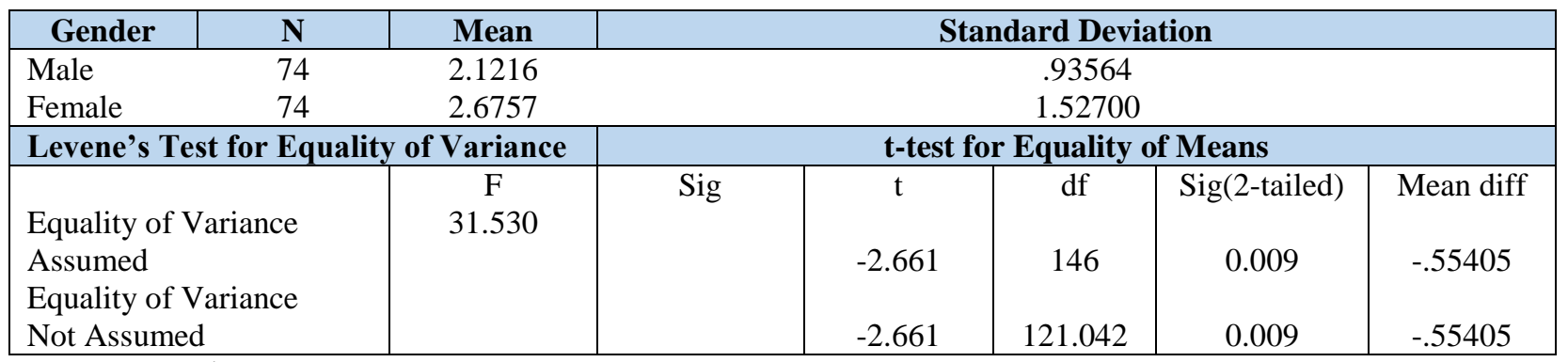

Source: Reseacher's fieldwork/computer output, 2018

\section{Hypotheses Testing}

Hypothesis One: There is no significant difference(s) in the knowledge of recreational activities by gender. 
Table 7, shows the analysis of variance on respondent's knowledge of recreation based on gender. The male respondents mean value is 3.500, while that of the female is 1.4189. Similarly, the table revealed that the F value (1.870) is not significant. That is, the observed difference in the mean values of both the male and female sex is not significant, $F(1,146)=1.870, p>0.05$. Therefore, since the one-way, failed to reveal a reliable difference in respondents' knowledge of recreation based on sex, the null hypothesis which states that there is no significant difference in gender knowledge of recreation is accepted.

Table 7. Analysis of variance on gender participation in recreation.

\begin{tabular}{lcccccc}
\hline Gender & N & Mean & SD & Df & F-value & p-value \\
\hline Male & 74 & 3.500 & 1.97415 & 1 & 1.870 & .174 \\
Female & 74 & 1.4189 & 1.47646 & 146 & & \\
\hline Source: & &
\end{tabular}

Source: Researcher's fieldwork/computer output, 2018

\section{Hypothesis Two: There is no significant difference in gender participation in recreation.}

As seen in Table 8 , the mean value of the male respondents 1.4730 , while that of the female is 1.4189. It can be observed that the mean value for the male respondents is higher than that of the female respondents. In order to know whether this difference is due to chance or is statistically significant, the table further shows that the $F$ ratio $(0.433)$ is not significant $(p>0.50)$. This shows that there is no significant difference in gender participation in recreation $\mathrm{F}(1,146)=0.433$, $\mathrm{p}$. 0.05 .

Table 8. Mean, standard deviation and t-value on the respondents' recreation behaviour based on gender

\begin{tabular}{lcccccc}
\hline Gender & N & Mean & SD & Df & F-value & p-value \\
\hline Male & 74 & 1.4730 & 0.50 & 1 & .433 & .512 \\
Female & 74 & 1.4189 & 0.49 & 146 & & \\
\hline Source & &
\end{tabular}

Source: Researcher's fieldwork/computer output, 2018

\section{Factor analysis on factors influencing recreation behaviour among the respondents}

Table 9 depicts the information regarding the fifteen possible variables influencing recreation behaviour among the respondents and their relative explanatory power as expressed by their Eigen values. These factors include age, gender, academic qualification, status/position, accessibility to recreational facilities, marital status, available time, peer influence, lifestyle, work schedule, awareness, health status, money, interest and existence of official policy. Factor 1 (Age) explains $36.46 \%$ of the total variance, while Factor 2 (Gender) and 3 (academic qualification) explain $19.50 \%$ and $13.73 \%$ of the total variance respectively. Factor 4 (status/position) accounts for $10.33 \%$ of total variance. Only Factor 5 (Accessibility to recreational facilities) explains $9.62 \%$ of the total variance. In addition, as seen in Table 10 the sum of square for each the four factors are 5.470, 2.924, 2.061, 1.549 and 1.443 respectively. These factors are extracted in order of their importance, with factor 1 (age) accounting for highest variance and factor 5 (Accessibility to recreational facilities) low. 
Table 9. Total variance explained

\begin{tabular}{|c|c|c|c|c|c|c|c|c|c|}
\hline \multirow[b]{2}{*}{ Component } & \multicolumn{3}{|c|}{ Initial Eigen values } & \multicolumn{3}{|c|}{$\begin{array}{l}\text { Extraction Sums of } \\
\text { Squared Loadings }\end{array}$} & \multicolumn{3}{|c|}{$\begin{array}{c}\text { Rotation Sums of Squared } \\
\text { Loadings }\end{array}$} \\
\hline & Total & $\begin{array}{c}\text { \% of } \\
\text { Variance }\end{array}$ & $\underset{\%}{\text { Cumulative }}$ & Total & $\begin{array}{c}\% \text { of } \\
\text { Variance }\end{array}$ & $\underset{\%}{\text { Cumulative }}$ & Total & $\begin{array}{c}\% \text { of } \\
\text { Variance }\end{array}$ & $\underset{\%}{\text { Cumulative }}$ \\
\hline 1 & 5.470 & 36.464 & 36.464 & 5.470 & 36.464 & 36.464 & 3.855 & 25.697 & 25.697 \\
\hline 2 & 2.924 & 19.495 & 55.960 & 2.924 & 19.495 & 55.960 & 2.887 & 19.248 & 44.945 \\
\hline 3 & 2.061 & 13.739 & 69.698 & 2.061 & 13.739 & 69.698 & 2.710 & 18.069 & 63.014 \\
\hline 4 & 1.549 & 10.325 & 80.023 & 1.549 & 10.325 & 80.023 & 2.032 & 13.543 & 76.557 \\
\hline 5 & 1.443 & 9.619 & 89.642 & 1.443 & 9.619 & 89.642 & 1.963 & 13.084 & 89.642 \\
\hline 6 & .577 & 3.849 & 93.490 & & & & & & \\
\hline 7 & .444 & 2.958 & 96.448 & & & & & & \\
\hline 8 & .297 & 1.982 & 98.430 & & & & & & \\
\hline 9 & .164 & 1.090 & 99.521 & & & & & & \\
\hline 10 & .072 & .479 & 100.000 & & & & & & \\
\hline 11 & $3.201 \mathrm{E}-15$ & $2.134 \mathrm{E}-14$ & 100.000 & & & & & & \\
\hline 12 & $2.220 \mathrm{E}-15$ & $1.480 \mathrm{E}-14$ & 100.000 & & & & & & \\
\hline 13 & $1.772 \mathrm{E}-15$ & $1.182 \mathrm{E}-14$ & 100.000 & & & & & & \\
\hline 14 & $1.291 \mathrm{E}-16$ & $8.606 \mathrm{E}-16$ & 100.000 & & & & & & \\
\hline 15 & $-1.623 \mathrm{E}-15$ & $-1.082 \mathrm{E}-14$ & 100.000 & & & & & & \\
\hline
\end{tabular}

Extraction method: Principal Component Analysis

Source: Researcher's fieldwork, 2018

Generally, these five factors account for $89.64 \%$ of the total variation. Since this index $(89.64 \%)$ is more than $50 \%$, it is sufficient to say the variables under study are somehow related to one another. In addition, Table 9 shows communalities after extraction. Large communalities indicate that a large amount of the variance in a variable has been extracted by the factor solution. Small commonalities indicate a large part of the variance in a variable is unaccounted for by the factor. The amount of variance in each variable that can be explained by the retained factors is represented by the communalities after extraction. As seen in the table, the communality $0.949 \%$ for variable 13 (academic qualification) indicates that the variance associated with this variable (academic qualification) is common with other variables included in the analysis than do variables like interest and lifestyle of the benefits of recreation $0.825 \%$, and $0.834 \%$ respectively. Similarly, as further seen on Table 10, academic qualification (.951); status/position (.906); life style (.825) marital status (.573); loaded highly on factor one. These factors relate to socio-economic characteristics of the respondents. Furthermore, gender (.900); availability of time (.953) and interest (.842) loaded highly on factor two. This relates to availability of time for interested respondents to participate in recreation. Existence of official polity (.816); work schedule (.787); money (.680) and peer influence (.669) loaded highly on factor three.

Thus, the third factor influencing recreation behaviour in the study area relates to a combination of individual financial/work strength and influence from both the employers and coworkers. In addition, age (.929); accessibility to recreational facilities (.679) and awareness of the benefits of recreation (.643) loaded highly on factor three. This relates to availability of recreational facilities for different age groups and awareness of the benefits of recreation. Only 
health status (.944) loaded highly on factor five. Hence, factors influencing recreational behaviour among the respondents include socio-demographic characteristics, availability of time for interested participants, external influence from peers and work place, availability of recreational facilities for different age groups and the health status of the participants.

Table 10. Rotated component matrix

\begin{tabular}{|c|c|c|c|c|c|c|}
\hline & & & & Component & & \\
\hline & Age & $\begin{array}{c}\text { Availability } \\
\text { of time }\end{array}$ & Awareness & $\begin{array}{l}\text { Recreational } \\
\text { facilities }\end{array}$ & $\begin{array}{l}\text { Health } \\
\text { status }\end{array}$ & Communalities \\
\hline Age & & & & .929 & & .874 \\
\hline Gender & & .900 & .142 & .237 & & .886 \\
\hline Academic qualification & .951 & & & .187 & & .949 \\
\hline Employment & .906 & & & .166 & -.222 & .909 \\
\hline $\begin{array}{l}\text { Accessibility to recreational } \\
\text { facilities }\end{array}$ & .472 & .414 & .233 & .676 & -.166 & .933 \\
\hline Marital status & .573 & .161 & .263 & & -.663 & .868 \\
\hline Availability of time & .146 & .953 & .173 & & & .961 \\
\hline peer influence & .615 & & .668 & -.206 & & .869 \\
\hline Life style & .825 & -.184 & & & & .834 \\
\hline Work schedule & -.319 & & .787 & .291 & .263 & .875 \\
\hline Awareness & .198 & .128 & & .643 & .569 & .928 \\
\hline Health status & & & & -.147 & .944 & .932 \\
\hline Money & .471 & .440 & .680 & .142 & -.142 & .919 \\
\hline Interest & -.149 & .842 & & & .142 & .825 \\
\hline Existence of official policy & .334 & & .816 & & -.319 & .883 \\
\hline & & & & & & Total \\
\hline Sum of squares (Eigen values) & 5.470 & 2.924 & 2.061 & 1.549 & 1.443 & 13.447 \\
\hline Percentage of Trace & 36.464 & 19.495 & 13.739 & 10.325 & 9.619 & 89.642 \\
\hline
\end{tabular}

Source: Researcher's fieldwork/computer output, 2018

\section{Conclusion and recommendations}

The study has actually revealed that the factors influencing recreational behaviour among the respondents include socio-demographic characteristics, availability of time for interested participants, external influence from peers and work place, availability of recreational facilities for different age groups and the health status of the participants. Hence, there is no significant difference in gender knowledge of recreation and in gender participation in recreation but they have different recreational activities which are mostly passive in nature. The study thus recommends that educative seminars and proper awareness should be created more for all members of academic staff, in order to sensitize them on the importance of active recreation as most of them are engaged in passive recreation. Members of the academic staff and the university community at large should be encouraged to participate in the various recreational activities by making use of different recreational facilities available within the institution. This will enhance the physical and psychological wellbeing of the academic members of staff of the 
university. Hence, higher learning institutions' involvement in recreation may be an alternative for work life balance. The implication of these findings is that it will enable every individual to have an in-depth knowledge of the importance of active recreation to the well being of an individual regardless of type of profession engaged in.

\section{References}

Adeniyi, A. (2013). Impact of Climate on Productivity of Selected Crops in Ilorin, Kwara State, Nigeria. Ilorin Journal of Social Sciences, 15(1): 59-66.

Akindutire, I.O., \& Oyeniyi, P. (2012). Inhibiting factors to female participation in sport in Nigerian universities. European Scientific Journal, 8(21), 76-82.

Akinmade, O. (2000). Teaching education in the 21st century Nigeria: Challenges and strategies. Nigeria: University of Jos.

Amusa, L.O. (1985). The place of recreation in preventive medicine. Proceeding of the 16th Annual Conference of NAPHER. Calanar 61-64.

Bem, L.S. (2010). Gender childhood and family life. In Laura Kramer (Eds.), Sociology of gender: A brief introduction. Oxford, UK: Oxford University Press.

Bucher, C.A. (1979). Foundation of physical education. St Louis: The C.V. Mosby Company Ltd.

Bucher, C.A. (1983). Administration of Physical Education. St. Louis: C. V. Mosby Company Ltd.

Buckland, L., \& Haleegoah, J. (1996). Gender analysis in agricultural production. IITA Research Guide 58. Training Program International Institute of Tropical Agriculture (IITA). Ibadan, Nigeria

Emeribe, V.C., \& Akah, L.U. (2012). Knowledge, attitude and participation of male and female nurses in recreational cctivities in Cross River State, Nigeria. Canadian Social Science, 8(4), 150-153. https://doi.org:10.3968/j.css.1923669720120804.1814

Falade, J.B. (1990). Tourism in Nigeria. Tourism Management, 11(3), 257-262.

Gunther, D., \& Zimprich, E. (1997). Gender orientation in the post harvest sector. Pointers for identifying gender-specific aspect on the post harvest sector. Deutshe Gesellechaft Technishe.

Hammond, R., \& McCullagh, P. (1978). Quantitative techniques in Geography. Oxford: Oxford University Press Limited.

Jones, B., Kennaugh, J., Parry, C., \& Ross, J. (1996). Leisure and tourism G.N.V.O: Advanced Text Book. Great Britain: Butterworth-Heinemann.

Moser, C. (1989). Gender planning in the Third World: Meeting practical and strategic gender needs. World Development, 17(11 November), 1799-1825.

Nirmal, K.H.S., Lai, W.S., \& Mohd, N.M.S. (2018). Impact of education levels on economic growth in Malaysia: A gender base analysis. Geografia-Malaysian Journal of Society and Space, 14(4), 13-26 https://doi.org/10.17576/geo-2018-1404-02

Nithiya, G.S., Premalatha, K., \& Parthiban, S.G. (2018). Gender socialization and capability deprivation on child urban poverty: Experiences of Malaysian Indian women. GeografiaMalaysian Journal of Society and Space, 14(4), 346-356. https://doi.org/10.17576/geo2018-1404-28 
Obinna, V., Owei, O., Ayodele, A., \& Okwakpam, I. (2009). Patterns and determinants of recreational behaviour in Port Harcourt, Rivers State, Nigeria. Theoretical and Empirical Researches in Urban Management, 3(12), 150-165.

Olubor, R.O., \& Osunde, U.A. (2007). Analysis of personal study time and leisure among university undergraduates in Southern Nigeria. College Student Journal. 41(2), 362-365.

Olowoyo, G.O. (1986). Recreation: A fundamental and universal human need. Proceedings of the 16th Annual Conference of the Nigeria Association for Physical Health Education and Recreation, Calabar, 121-128.

Omolawon, K.O., \& Mohammed, S. (2006). Perceived determinants associated with nonparticipation of University of Ibadan academic staff in sport and physical activities. Journal of International Council for Health, Physical Education, Recreation, sport and Dance, 1(2), 97-100.

Ostergaard, L. (1992). Gender and Development: A Practical Guide. London: Routledge

Russo, S., Bremer F.J., Poats, S., \& Laurene, G. (1989). Gender issues in agriculture and natural resource management. Washington, D.C.: USAID.

United Nations. (2007). The Millennium Development Goals Report (2007). New York. Retrieved from https://www.un.org/millenniumgoals/pdf/mdg2007.pdf

World Health Organization. (2018). Physical activity. Retrieved from https://www.who.int/newsroom/fact-sheets/detail/physical-activity 